\title{
Modelling atmospheric OH-reactivity in a boreal forest ecosystem
}

\author{
D. Mogensen ${ }^{1,2}$, S. Smolander ${ }^{1}$, A. Sogachev ${ }^{3}$, L. Zhou ${ }^{1}$, V. Sinha ${ }^{4,5}$, A. Guenther ${ }^{6}$, J. Williams ${ }^{4}$, T. Nieminen ${ }^{1}$, \\ M. K. Kajos ${ }^{1}$, J. Rinne ${ }^{1}$, M. Kulmala ${ }^{1}$, and M. Boy ${ }^{1}$ \\ ${ }^{1}$ Division of Atmospheric Sciences, Department of Physics, P.O. Box 48, University of Helsinki, 00014, Finland \\ ${ }^{2}$ Helsinki University Centre for Environment, P.O. Box 27, University of Helsinki, 00014, Finland \\ ${ }^{3}$ Wind Energy Division, Ris $\varnothing$ National Laboratory for Sustainable Energy, Technical University of Denmark, Building 118, \\ Box 49, 4000, Roskilde, Denmark \\ ${ }^{4}$ Max Planck Institute of Chemistry, J. Becher Weg 27, 55128 Mainz, Germany \\ ${ }^{5}$ Indian Institute of Science Education and Research (IISER) Mohali, MGSIPAP Complex, Sector 26, Chandigarh \\ 160019, India \\ ${ }^{6}$ National Center for Atmospheric Research, Boulder, CO 80307, USA
}

Received: 11 March 2011 - Published in Atmos. Chem. Phys. Discuss.: 17 March 2011

Revised: 29 July 2011 - Accepted: 12 September 2011 - Published: 20 September 2011

\begin{abstract}
We have modelled the total atmospheric $\mathrm{OH}$ reactivity in a boreal forest and investigated the individual contributions from gas phase inorganic species, isoprene, monoterpenes, and methane along with other important VOCs. Daily and seasonal variation in OH-reactivity for the year 2008 was examined as well as the vertical $\mathrm{OH}$ reactivity profile. We have used SOSA; a one dimensional vertical chemistry-transport model (Boy et al., 2011a) together with measurements from Hyytiälä, SMEAR II station, Southern Finland, conducted in August 2008. Model simulations only account for $\sim 30-50 \%$ of the total measured $\mathrm{OH}$ sink, and in our opinion, the reason for missing $\mathrm{OH}$ reactivity is due to unmeasured unknown BVOCs, and limitations in our knowledge of atmospheric chemistry including uncertainties in rate constants. Furthermore, we found that the OH-reactivity correlates with both organic and inorganic compounds and increases during summer. The summertime canopy level $\mathrm{OH}$-reactivity peaks during night and the vertical OH-reactivity decreases with height.
\end{abstract}

\section{Introduction}

The hydroxyl radical $(\mathrm{OH})$ is the most important oxidant in the atmosphere. Understanding both the sources and sinks of $\mathrm{OH}$ is key to assessing the atmosphere's capacity to oxidise gas phase organic trace gases and produce secondary organic aerosols (SOA). While the production term during

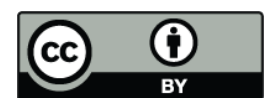

Correspondence to: M. Boy

(michael.boy@helsinki.fi) daytime for $\mathrm{OH}$ is reasonably well constrained by radiometer measurements $\left(\mathrm{JO}^{1} \mathrm{D}\right)$, the sink term (total OH-reactivity) was until recently only indirectly determined by summing the contributions of available measurements.

The application of Laser Induced Fluoresence (LiF) has allowed total $\mathrm{OH}$ lifetime and hence total $\mathrm{OH}$-reactivity $(\mathrm{OH}$-reactivity $=1 / \mathrm{OH}$ lifetime $)$ to be determined directly in campaigns such as PROPHET 2000 (di Carlo et al., 2004), INTEX-B (Mao et al., 2009), PMTACS-NY2001 (Ren et al., 2003) and PRD (Lou et al., 2010). Measuring the total OHreactivity using $\mathrm{LiF}$ is difficult since it requires the rapid measurement of $\mathrm{OH}$ at very low concentrations. In this study, we use a dataset acquired using an alternative method namely the comparative reactivity approach (Sinha et al., 2008). This technique circumvents the difficult task of measuring $\mathrm{OH}$ radicals directly and instead relies on the accurate measurement of pyrrole at high mixing ratios $(>15 \mathrm{ppbV})$ using a Proton Transfer Reaction - Mass Spectrometer (PTR-MS) (Sinha et al., 2010). Since measurement techniques provide data at a specific point for a limited period, modelling is needed in order to develop an overall spatial and temporal understanding of the total reactivity term and test the accuracy of chemical parametrizations by comparison with measurements.

OH-reactivity has previously been calculated in models, albeit with limited chemistry; (e.g. Apel et al., 2010) (including 85 chemical species, and 196 reactions), and from field measurements by adding the $\mathrm{OH}$-reactivity of the individually measured $\mathrm{OH}$ sinks (e.g. NMHCs, $\mathrm{CO}, \mathrm{CH}_{4}, \mathrm{NO}_{\mathrm{x}}$ ) (Chatani et al., 2009; Lou et al., 2010; Sinha et al., 2010; di Carlo et al., 2004). 
In this paper, we present simulated $\mathrm{OH}$-reactivities for one year in a boreal forest. The work focuses on the $\mathrm{OH}$ reactivity partly in order to investigate how well we understand the boundary layer $\mathrm{OH}$ chemistry and partly in order to gain a better understanding of the aerosol-precursors formed due to the reaction of volatile organic compounds (VOCs) and $\mathrm{OH}$. We have used data from the SMEAR II station, Hyytiälä, Southern Finland. We simulated over boreal forest, since these cover a significant part of the Earth's surface and emit large amounts of volatile organic compounds. In order to ascertain how well we understand the $\mathrm{OH}$-initiated photochemical processes, we have compared our calculated $\mathrm{OH}-$ reactivity with measured ambient $\mathrm{OH}$-reactivity from the BFORM (Boreal Forest OH Reactivity Measurements) campaign, August 2008 (Sinha et al., 2010) during which the total atmospheric $\mathrm{OH}$-reactivity was measured using the Comparative Reactivity Method (Sinha et al., 2008). However, the measured OH-reactivity data will not be analysed in detail here, but can be found in the paper by Sinha et al. (2010). We also present the modelled contributions to the OH-reactivity by several different types of trace gases, discuss the seasonal variation and present the vertical $\mathrm{OH}-$ reactivity profile.

\section{Model simulations}

The one-dimensional chemistry-transport model SOSA (Model to Simulate the concentrations of Organic vapours and Sulphuric Acid) was used in the calculations of the $\mathrm{OH}-$ reactivity (Boy et al., 2011a). This vertical transport model is based on the coupled plant-atmosphere boundary-layer model SCADIS (Sogachev et al., 2002, 2005; Sogachev and Panferov, 2006; Sogachev, 2009). The model runs without any continuous input besides the upper boundary meteorological conditions at $3 \mathrm{~km}$ and the long-range-influenced transported gases $\left(\mathrm{NO}_{\mathrm{x}}, \mathrm{SO}_{2}\right.$ and $\left.\mathrm{CO}\right)$ which are given at every time-step $(10 \mathrm{~min})$ from measurements with a vertical gradient estimated from simulations with the global aerosol model ECHAM5-HAM. The measured input data are obtained from the Station to Measure Ecosystem-Atmosphere Relation (SMEAR II) at Hyytiälä, Southern Finland. A detailed description of the station and instrumentation can be found under Kulmala et al. (2001) and http://www.atm. helsinki.fi/SMEAR/index.php, and a detailed description of the model-setup and of the measurements used in SOSA, can be found under Boy et al. (2011a).

\subsection{Meteorology and transport}

The meteorology is described by a one-dimensional version of the SCADIS model (Sogachev et al., 2002; Sogachev and Panferov, 2006; Boy et al., 2011a). Based on the Reynolds averaged Navier-Stokes (RANS) equations, SCADIS employs a turbulent kinetic energy - specific dissipation closure scheme. The model includes prognostic equations for these variables and for wind, heat and moisture. Involving a number of parametrizations the model is capable of describing in a realistic manner the physical processes forming the meteorological regime within and above the forest canopy under different environmental conditions. Further, measured meteorological data (temperature, humidity and wind speed, at 4 , $8,16,33,50$ and $67 \mathrm{~m}$ heights) from SMEAR II mast are used for nudging the model variables towards the observations. SCADIS describes the atmospheric boundary layer evolution and the mixing of the chemical species in a model domain of 51 layers. The resolution is higher near the ground, and the separation between layers increases progressively towards the model top, which is at $3000 \mathrm{~m}$.

\subsection{Emission}

No measured concentrations of organic compounds are used as input, due to the lack of information about the vertical distribution above the canopy. Instead the emissions of organic vapours from the canopy were calculated with a modification of the model MEGAN (Model of Emissions of Gases and Aerosols from Nature), version 2.04 (Guenther et al., 2006). This model, which has been implemented in SOSA, estimates landscape average emission factors for a specific location by combining estimates of plant species composition and representative species-specific emission factors. For each time step, emissions driven by changes in calculated leaf temperature and incident solar radiation on sun and shade leaves at different canopy levels, are calculated. We have assumed the landscape to be composed of Scots pine, and use standard emission potentials (for isoprene, sabinene, limonene, $\Delta^{3}$-carene, $\alpha$-pinene, $\beta$-pinene, ocimene, cineole, $\beta$-caryophyllene, farnesene, and 2-methyl-3-buten-2-ol) by Hakola et al. (2006). This is a good first order approximation even though it neglects the influence of other species in the concentration footprint (e.g. Haapanala et al., 2007).

The monoterpene emission of Scots pine is in the same range with other Eurasian coniferous trees (Rinne et al., 2009). However, the monoterpene species emitted vary between species and even within species. Individual Scots pine trees differ especially in there relative $\alpha$-pinene and $\Delta^{3}$-carene emissions, while the atmospheric concentrations at SMEAR II are dominated by $\alpha$-pinene. $\Delta^{3}$-carene reacts $64 \%$ faster with $\mathrm{OH}$ than $\alpha$-pinene does. The diurnal cycle of monoterpene emission and resulting atmospheric concentration can be different between the coniferous trees and monoterpene emitting deciduous boreal trees, which do not have night-time emission from specialized monoterpene storage structures. Thus the diurnal cycle of $\mathrm{OH}$-reactivity might be different where the vegetation is dominated by e.g. birches.

Also 16 different canopy characteristics, such as leaf data together with scattering and reflection coefficients are used to describe the needle forest. The emission scheme has been 
verified by comparing VOC gas concentrations in the paper by Boy et al. (2011a), but also in this publication (Sect. 4.3) we show good agreement between measured and modelled monoterpene concentrations. Model validation through comparison of different modelled and measured organic gas concentrations have been done and will be presented in the paper by Boy et al. (2011b).

\subsection{Chemistry}

The chemistry is calculated using the Kinetic PreProcessor (KPP) (Damian et al., 2002). Most chemical reaction equations were selected from the Master Chemical Mechanism v3.1 (Jenkin et al., 1997; Saunders et al., 2003) via website: http://mcm.leeds.ac.uk/MCM/. The chemistry includes 2140 reactions, and a total of 761 chemical species representing the complete reaction paths for isoprene, 2-methyl-3buten-2-ol, $\alpha$-pinene, $\beta$-pinene, methanol, acetone, acetaldehyde, formaldehyde, methane and relevant inorganic reactions. First order reactions between $\mathrm{OH}, \mathrm{O}_{3}, \mathrm{NO}_{3}$ and the following monoterpenes; $\Delta^{3}$-carene, limonene, sabinene, camphene, ocimene, cineole and a term called "other monoterpenes", were also included in the chemistry. Likewise, first order reactions between $\mathrm{OH}, \mathrm{O}_{3}, \mathrm{NO}_{3}$ and the following sesquiterpenes; $\beta$-caryophyllene, farnesene, and a term we call "other sesquiterpenes", were also included in the chemistry. The photochemistry has been improved by calculating the photodissociation constants more precisely using data from Atkinson et al. (1992) and spectral irradiance measurements from the SMEAR II station (Boy et al., 2002). In some cases we also used more recently obtained rate constants, e.g. for the reaction between acetone and $\mathrm{OH}$ (DeMore et al., 1997). Measured inorganic gas concentrations from SMEAR II are used as input. Furthermore, condensation sinks for sulphuric acid and nitric acid, based on DMPS (Differential Mobility Particle Sizer) and APS (Aerodynamic Particle Sizer) data, are included (Boy et al., 2003).

$\mathrm{OH}$-reactivity determines how fast the $\mathrm{OH}$ radical is lost from the atmosphere. OH-reactivity related to a single reaction is calculated by multiplying the reaction rate coefficient (between $\mathrm{OH}$ and the reactant) by the concentration of the reactant. The total $\mathrm{OH}$-reactivity is the sum over all these multiplication terms, for all sink reactions of $\mathrm{OH}$ (all reactions where $\mathrm{OH}$ reacts with a compound):

$$
R_{\mathrm{OH}}=\sum_{\text {Reactions }} k_{\mathrm{OH}+\mathrm{X}} \times[X]
$$

$R_{\mathrm{OH}}$ is the total $\mathrm{OH}$-reactivity, and $k_{\mathrm{OH}+\mathrm{X}}$ is the bimolecular reaction rate coefficient for the chemical reaction between the $\mathrm{OH}$ radical and the chemical species $X$, where the concentration of $X$ is given by $[X]$. In our definition of the $\mathrm{OH}$ reactivity, also the OH-reactivity due to reactions between $\mathrm{OH}$ and secondary or higher order reaction products arising from a primary reaction, are included. Only recycling mechanisms which are available through MCM version 3.1 are taken into account (e.g. the reactions which recycle $\mathrm{OH}$ through the $\mathrm{OH}-\mathrm{RO}_{2}-\mathrm{HO}_{2}-\left(\mathrm{NO}_{\mathrm{x}}\right)$ system. Recycling mechanisms through e.g. isoprene reactions Lelieveld et al., 2008) were not used in this study, but these will be investigated in a paper under preparation that discusses the $\mathrm{OH}$ budget in Hyytiälä.

The reaction equation files, from the Master Chemical Mechanism, are text files in KPP-format. We wrote a script in the Python programming language (using the pattern matching operations in the regular expressions module) to find the bimolecular reactions including $\mathrm{OH}$, and to postprocess them into additional "bookkeeping reactions", to calculate the time evolution of the $\mathrm{OH}$-reactivity along with the time evolution of the real chemicals. In the results, we use $30 \mathrm{~min}$ averages of $\mathrm{OH}-$ reactivity. (Sensitivity studies with averaging over different time slots showed no significant difference in results.)

\section{Measurements}

A list of measurements conducted during the $\mathrm{OH}$-reactivity measurement period can be found under Sinha et al. (2010) and further details about these can be found under Hari and Kulmala (2005). Inorganic gas concentrations were measured to be in the order of: $\mathrm{O}_{3}: \sim 2-11 \times$ $10^{11}$ molecules $\mathrm{cm}^{-3}$, NO: $\sim 3-4 \times 10^{9}$ molecules $\mathrm{cm}^{-3}$ (daytime), $\mathrm{NO}_{2}: \sim 1-6 \times 10^{10}$ molecules $\mathrm{cm}^{-3}, \mathrm{NO}_{3}: \sim 1-$ $3 \times 10^{7}$ molecules $\mathrm{cm}^{-3}, \mathrm{SO}_{2}: \sim 1-5 \times 10^{9}$ molecules $\mathrm{cm}^{-3}$, and CO: $\sim 3 \times 10^{12}$ molecules $\mathrm{cm}^{-3}$.

\subsection{OH-reactivity measurements}

OH-reactivity was measured in August 2008 during the Boreal Forest OH-Reactivity Measurement (BFORM) campaign using the comparative reactivity instrument described in detail by Sinha et al. (2008). Briefly, the measurement is an in situ competitive kinetics experiment in which a proton transfer reaction mass spectrometer (PTR-MS) is coupled to a turbulent flow glass reactor. Pyrrole $\left(\mathrm{C}_{4} \mathrm{H}_{5} \mathrm{~N}\right)$ is introduced into the reactor and its concentration (say $\mathrm{C} 1$ ) is monitored with a PTR-MS, in the air exiting the reactor. Then, synthetically generated $\mathrm{OH}$ radicals $([\mathrm{OH}]<$ [pyrrole $]$ ) are introduced into the reactor at a constant rate to react with pyrrole. This causes the initial concentration of pyrrole to decrease to concentration $\mathrm{C} 2$. When ambient air is introduced into the reactor, the various species present in it compete with pyrrole for the $\mathrm{OH}$, so that the concentration of pyrrole increases to C3. Comparing the amount of pyrrole exiting the reactor in the zero air (C2) and ambient air (C3), allows the introduced air samples $\mathrm{OH}$-reactivity to be determined, provided the system is suitably calibrated for pyrrole (Sinha et al., 2009). The detection limit for the OH-reactivity measurements was $3.5 \mathrm{~s}^{-1}$, while the overall uncertainty of the measured $\mathrm{OH}$ reactivity is $\sim 20 \%$. Further details regarding technical aspects 
and sampling can be found in Sinha et al. (2010). Unfortunately, no $\mathrm{OH}$ concentration measurements were obtained.

\subsection{VOC measurements}

VOC measurements were conducted using the PTR-MS that operates permanently at the SMEAR II station (Taipale et al., 2008). Ambient air was sampled from a scaffolding tower located approximately $20 \mathrm{~m}$ from the $\mathrm{OH}$-reactivity sampling. Samples were taken from three heights: 4,14 , and $22 \mathrm{~m}$. The PTR-MS measured masses 33, 59, 45, 47, 61, 69, 71, 73, 87, 93, 101, 137 and 81, and 169 which have been attributed to methanol, sum of acetone and propanal, acetaldehyde, formic acid, acetic acid, isoprene, sum of methacrolein and methyl vinyl ketone, methyl ethyl ketone, methyl butenol, toluene, sum of cis-3 hexenol and hexanal, sum of monoterpenes, and pinonaldehyde, respectively. These identifications are in keeping with previous PTR-MS studies although minor contributions from other species cannot be ruled out (Taipale et al., 2008; de Gouw and Warneke, 2007). The overall uncertainty of the VOC measurements was estimated to be $15 \%$ (Taipale et al., 2008). Ambient air measurements were available daily for the following hours: $1-2,4-5,7-$ $8,10-11,13-14,16-17,19-20,22-23$, as chamber and flux measurements were conducted during the other time spans.

\section{Results and discussion}

The OH-reactivity was measured from the 12 August evening until the morning of the 28 August 2008. Due to a pollution event on the 27 th, we only compare our modelled data with measured data in the period from 13th at 00:00 o'clock to the 26th at 24:00 o'clock. We refer to this period as "Period A". Due to a generally higher measured $\mathrm{OH}$-reactivity in the first part of Period A, we further separate this into two subperiods: "Period B" starting from the 13th at 00:00 o'clock to the 18th at 24:00 o' clock, and "Period C" starting from the 19th at 00:00 o'clock to the 26th at 24:00 o'clock. We will analyse these subperiods separately and compare them to the full period (Period A). The canopy height in Hyytiälä is set to $15 \mathrm{~m}$ in our model. The OH-reactivity was measured at a height of approximately $12-14 \mathrm{~m}$ and modelled at the height of $14 \mathrm{~m}$ if not mentioned otherwise.

In Fig. 1, 30 min resolution measured and modelled $\mathrm{OH}-$ reactivity in August 2008 is presented. The average modelled OH-reactivity in Period A is calculated to be $2.5 \mathrm{~s}^{-1}$ with the lowest value of $1.7 \mathrm{~s}^{-1}$ and the highest value of $4.4 \mathrm{~s}^{-1}$ showing little variability in contrast to the measured data where great fluctuation is observed over short time scales. This high measured fluctuation could be due to locally strong turbulence and time-dependent emission peaks which are not included in our model, that assumes a more homogeneous forest. However, we do not observe any large fluctuation in the total sum of measured monoterpenes.

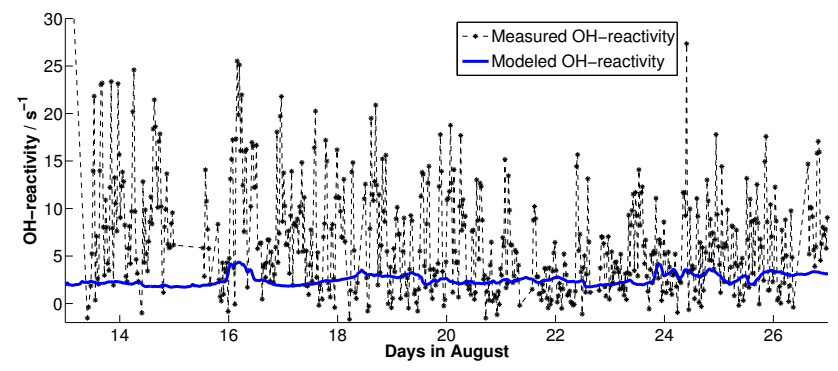

Fig. 1. Modelled (blue) and $30 \mathrm{~min}$ resolution measured $\mathrm{OH}-$ reactivity (black) from the 13 to 27 August 2008 .

Table 1. Modelled, measured and missing OH-reactivity for 13 to 27 August 2008 given as mean. Standard deviations are given in parenthesis.

\begin{tabular}{lrrr}
\hline & $\begin{array}{r}13-27 \text { Aug } \\
\left(\mathrm{s}^{-1}\right)\end{array}$ & $\begin{array}{r}13-18 \text { Aug } \\
\left(\mathrm{s}^{-1}\right)\end{array}$ & $\begin{array}{r}19-27 \text { Aug } \\
\left(\mathrm{s}^{-1}\right)\end{array}$ \\
\hline Modelled OH-reactivity & $2.5( \pm 0.6)$ & $2.3( \pm 0.6)$ & $2.6( \pm 0.5)$ \\
Measured OH-reactivity & $6.5( \pm 6.7)$ & $8.6( \pm 7.8)$ & $5.1( \pm 5.4)$ \\
Missing OH-reactivity & $4.0 / 61 \%$ & $6.2 / 73 \%$ & $2.5 / 49 \%$ \\
\hline
\end{tabular}

Modelled, measured and missing OH-reactivity for the three periods are listed in Table 1. The mean modelled $\mathrm{OH}_{-}$ reactivity in Period B is $2.3 \mathrm{~s}^{-1}$ and in Period C $2.6 \mathrm{~s}^{-1}$ leading to a missing OH-reactivity of $6.2 \mathrm{~s}^{-1}(\sim 70 \%)$ and $2.5 \mathrm{~s}^{-1}(\sim 50 \%)$, respectively. On average we underestimate the total OH-reactivity by $\sim 60 \%$, but for extensive periods the modelled reactivity is within the uncertainty of the measured values. In some periods the model overestimates the measurements.

The large values of missing $\mathrm{OH}-$ reactivity over the two weeks arise from a more or less constant modelled $\mathrm{OH}-$ reactivity within the whole Period $\mathrm{A}$, but a much higher measured $\mathrm{OH}$-reactivity in the first week $\left(8.6 \mathrm{~s}^{-1}\right)$ than in the last week $\left(5.1 \mathrm{~s}^{-1}\right)$. Analysing the measured and modelled gas concentrations, it was found that the concentrations of those species contributing significantly to the $\mathrm{OH}$-reactivity, were constant during the entire selected Period A, or slightly lower during Period B than Period C. This automatically results in higher modelled $\mathrm{OH}$-reactivity in Period $\mathrm{C}$. The temperature difference between the two periods was small; on average it was $1.3 \mathrm{~K}$ colder during the last week. As previous hydrocarbon flux measurements show, emissions decrease with temperature, which will decrease the OH-reactivity (Rinne et al., 2007). The emission flux of monoterpenes from the canopy is modelled to be higher in period $\mathrm{B}$, which could mean that we have an underestimation in the model of monoterpenes going out of the canopy. However, a decrease in temperature could also decrease the boundary layer height, which will cause an increase in $\mathrm{OH}$-reactivity. The vertical potential 


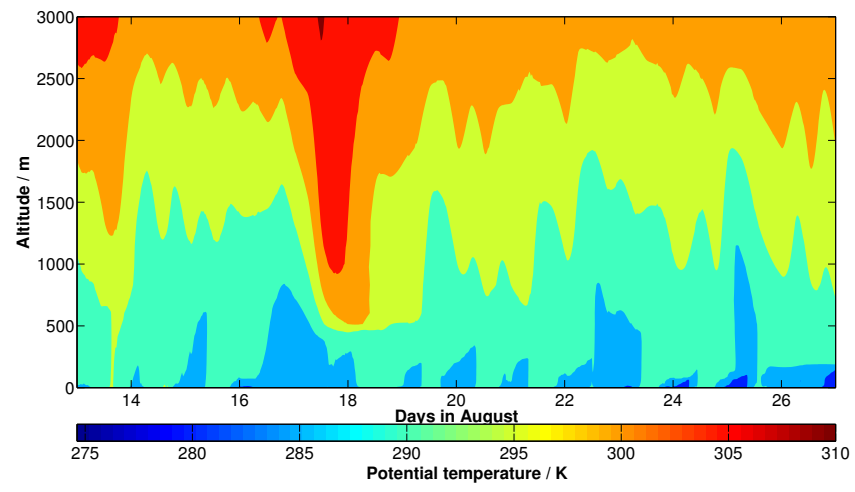

Fig. 2. Boundary layer heights expressed by potential temperature.

temperature is presented in Fig. 2. The boundary layer during day is found between $\sim 500-1400 \mathrm{~m}$, and during night between $\sim 100-300 \mathrm{~m}$, with an exception of the night between the 17 th and the 18 th, where the boundary layer drops significantly together with a sharp drop in temperature. As also mentioned in the detailed paper on the measurements from the BFORM campaign, the missing $\mathrm{OH}$ reactivity fraction was highest on this particular night and not during the mentioned pollution event on 27 August (Sinha et al., 2010).

\subsection{Contributions to the OH-reactivity}

The modelled OH-reactivity depends on the chemical contributions. In Fig. 3, calculated contributions to the $\mathrm{OH}$ reactivity from the 13 to 27 August 2008 are visualized. 12 compounds are included in "Inorganics"; $\mathrm{CO}, \mathrm{O}_{3}, \mathrm{H}_{2}$, $\mathrm{H}_{2} \mathrm{O}_{2}, \mathrm{HO}_{2}, \mathrm{NO}, \mathrm{NO}_{2}, \mathrm{NO}_{3}, \mathrm{HO}_{2} \mathrm{NO}_{2}, \mathrm{HONO}, \mathrm{HNO}_{3}$, and $\mathrm{SO}_{2}, 9$ compounds are included in "Monoterpenes"; $\alpha$-pinene, $\beta$-pinene, $\Delta^{3}$-carene, limonene, sabinene, camphene, ocimene, cineole and "other monoterpenes", while 415 compounds are included in "Other organics", with the label referring to include other organics than monoterpenes, isoprene and methane. "Other organics" mainly consists of second and higher order organic reaction products. The only primary emitted organic compounds that are also included in this group are $\beta$-caryophyllene, farnesene and 2-methyl-3-buten-ol.

According to our simulations the largest $\mathrm{OH}$ sink in $\mathrm{Au}-$ gust is organic compounds, which makes up $\sim 60 \%$ of the total calculated $\mathrm{OH}$-reactivity. The most important contributing VOCs are monoterpenes $\left(\sim 0.6 \mathrm{~s}^{-1}\right)$, isoprene $\left(\sim 0.2 \mathrm{~s}^{-1}\right)$, and methane $\left(\sim 0.2 \mathrm{~s}^{-1}\right)$. It seems that the known secondary organic reaction products (those we have included in our model) do not contribute significantly to the $\mathrm{OH}$-reactivity. The inorganic contribution is very significant with an $\mathrm{OH}-$ reactivity of $\sim 1.0 \mathrm{~s}^{-1}$, with $\mathrm{CO}$ contributing about $65 \%$ of the total inorganic contribution to the $\mathrm{OH}$-reactivity. The sum of the contributions from the inorganic compounds and

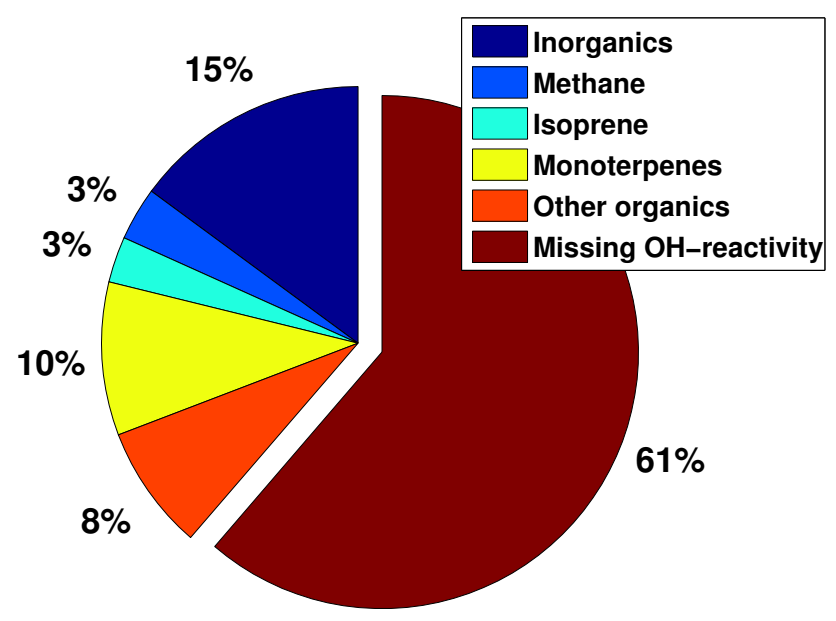

Fig. 3. Calculated contributions to the $\mathrm{OH}$-reactivity from the 13 to 27 August 2008.

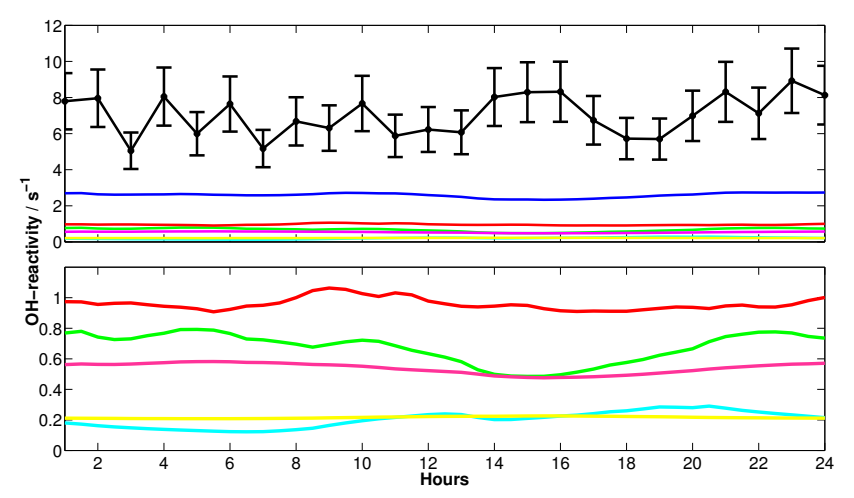

Fig. 4. Top figure: Measured (black) and modelled (dark blue) $\mathrm{OH}-$ reactivity including contributions from inorganic compounds (red), isoprene (light blue), monoterpenes (green), methane (yellow) and other organic compounds (pink). Bottom figure: Zoom of the contributions to the OH-reactivity. The color code is the same as in the top figure. In both figures the $\mathrm{OH}$-reactivity is given as daily average for Period A.

methane make up $18 \%$ of the measured $\mathrm{OH}$-reactivity, which is consistent with the findings of Sinha et al. (2010).

In Fig. 4, measured and modelled OH-reactivities, including contributions to the modelled $\mathrm{OH}$-reactivity for Period A, are presented as hourly averaged data. For the measured reactivity, $10 \mathrm{~min}$ resolution data has been used. Error bars of $20 \%$ on the measured data have been determined by Sinha et al. (2010). For the SOSA model there are too many parameters included in order for us to give a good uncertainty estimate, and therefore no error bars have been included on the modelled data. However, later on we perform a sensitivity study on the rate coefficients included (see Sect. 4.4). Sinha et al. (2010) also calculated the 


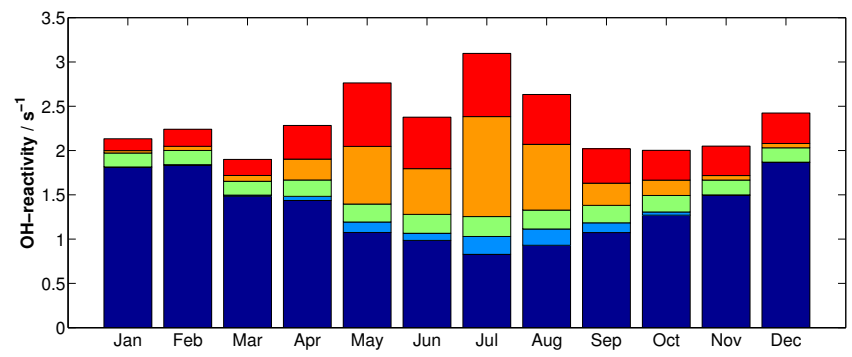

Fig. 5. Modelled OH-reactivity for year 2008 including contributions from inorganic compounds (dark blue), isoprene (light blue), methane (lime), monoterpenes (orange) and other VOCs (red).

contribution from monoterpenes to the OH-reactivity. However, while we find the contribution to be of $0.6 \mathrm{~s}^{-1}$, Sinha et al. (2010) find it to be of $1.0 \mathrm{~s}^{-1}$. This is due to the differences in calculation; Sinha et al. (2010) calculate the contribution using PTR-MS mass signals and a weighted average of the rate coefficients for the different monoterpenes based on 1.5-2 days of available GC-MS data, while we specifically model the individual monoterpene concentrations and their respective contributions to the $\mathrm{OH}$-reactivity. Due to large differences in rate constants, it is easy to get very different contributions from monoterpenes if a wrong monoterpene is assumed to dominate. Model simulations found that the order of OH-reactivity contributions from the individual monoterpenes is as follows: $\Delta^{3}$-carene $\sim \alpha$ pinene $>\beta$-pinene $>$ camphene $\sim$ "other monoterpenes" $>$ cineole $\sim$ sabinene $>$ limonene $\gg$ ocimene.

\subsection{Seasonal variation}

In Fig. 5, modelled contributions to the OH-reactivity throughout the year 2008 are shown. During the winter months the $\mathrm{OH}$-reactivity sink is dominated by inorganic compounds, whereas during summer, where the $\mathrm{OH}$ reactivity and VOC emissions peak, the overall sink is dominated by organic compounds. Throughout the year, $\mathrm{CO}$ is the most contributing inorganic species, closely followed by $\mathrm{NO}_{2}$. Since $\mathrm{CO}$ is the most contributing inorganic species throughout the year, the inorganic OH-reactivity pattern follows the CO concentration seasonal pattern, with higher levels in winter and spring and lower in summer.

The largest difference in monthly OH-reactivity is found between the months of March (lowest) and July (highest), with the difference being $\sim 1.3 \mathrm{~s}^{-1}$. Due to a still high missing fraction of unknown organic molecules in our model, we would expect that the missing $\mathrm{OH}-$ reactivity would be greatest in summer when the temperature is higher and the emissions larger (Goldstein and Galbally, 2007). According to our model, the OH-reactivity was expected to increase significantly from April 2008 to May 2008, and then decrease in June 2008. This is mainly due to much lower tempera-

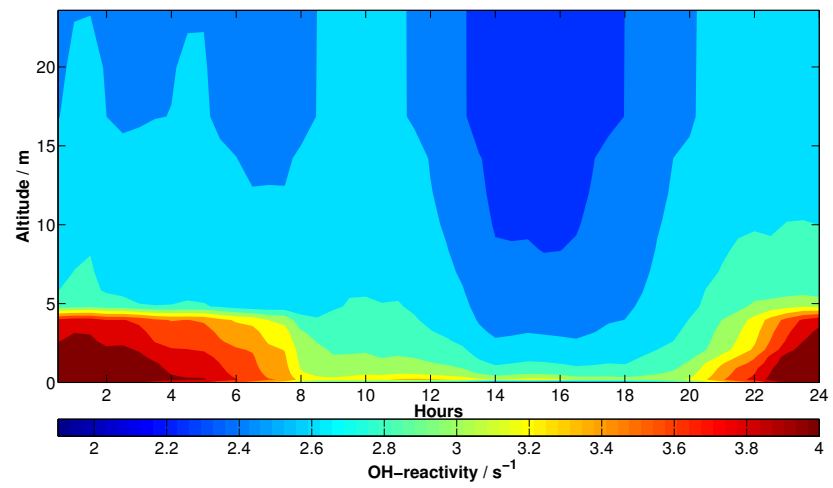

Fig. 6. Daily averaged modelled $\mathrm{OH}-$ reactivity from 13 to $27 \mathrm{Au}-$ gust as a function of altitude.

tures and boundary layer in May 2008, and to low contributions from isoprene in June. Comparisons of measured and modelled isoprene concentration for 2008 indicate that the model underestimates the isoprene concentration in June. Previous studies have shown that Scot pine forests, such as the Hyytiälä site, have a low isoprene emission (Rinne et al., 2009). However, in the area contributing to the measured concentrations, isoprene emitting tree species, such as Norway spruce, European aspen and willows are more common (Haapanala et al., 2007; Rinne et al., 2009). As most of the isoprene is not emitted at the site, but advected from nearby areas, it is difficult to describe this with a column model. Therefore it is not reasonable to force our model to fit the measured isoprene concentrations.

\subsection{Vertical profile of the OH-reactivity}

Daily averaged modelled OH-reactivity from ground to approximately $10 \mathrm{~m}$ above the canopy is visualized in Fig. 6 (the averaging has been done over the period: 13-26 August, 2008). The vertical OH-reactivity profile in summer (averaging from May-August) is presented in Fig. 7. A night time peak in the $\mathrm{OH}$-reactivity is observed in both figures. This peak is more pronounced below the canopy, but weakly observable also above. This is in contrast with the measured $\mathrm{OH}$-reactivity, in which no discernible diurnal cycle can be seen (Sinha et al., 2010). Figure 8 presents daily averaged modelled and measured monoterpene concentrations for 4 , 14 , and $22 \mathrm{~m}$ (averaged from the 26 July to the 10 August, 2008). This shows a night time peak in the monoterpene concentrations corresponding to that in the $\mathrm{OH}-$ reactivity. These peaks are found near ground due to continuing emission while the vertical mixing is suppressed. During day when the atmosphere is better mixed, the canopy OH-reactivity decreases. The measured vertical profile of monoterpene concentration also support these observations (Fig. 8). As also seen from Fig. 8, only a marginal difference between measured and modelled concentrations for all three heights are 


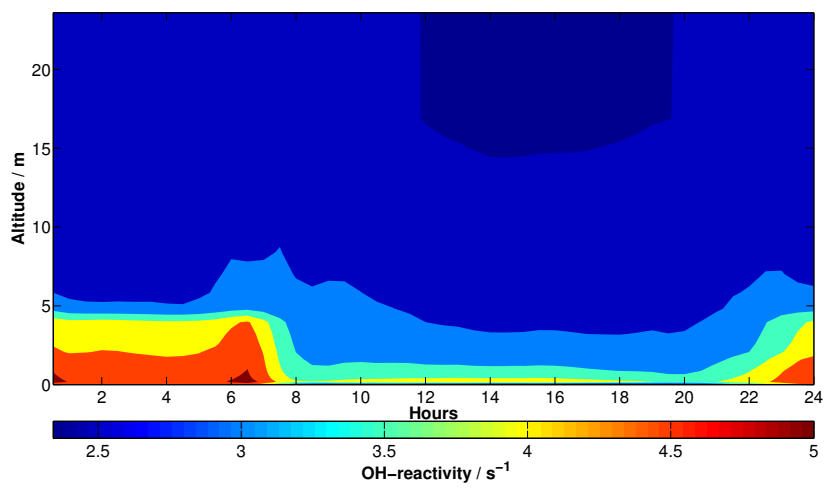

Fig. 7. Daily averaged modelled OH-reactivity as a function of altitude for May, June, July, and August 2008.

observed, verifying the emission scheme and chemistry included in our model. The reason for the lack of diurnal cycle in the observed $\mathrm{OH}$-reactivity may lie in the contrasting diurnal cycles of isoprene and monoterpene concentrations. While monoterpene concentrations at sites dominated by conifers tend to have their maximum at night due to the emission from storage pools, the maximum of isoprene concentration is usually observed in the afternoon (e.g. Rinne et al., 2005). The vegetation at the immediate vicinity of the measurement site is dominated by Scots pine emitting monoterpenes, but very little isoprene (Rinne et al., 2007, 2009). However, in the concentration footprint of the measurement site, Norway spruce dominated forests are as abundant as Scots pine dominated ones (Haapanala et al., 2007). Norway spruce is a significant source of isoprene into the atmosphere, as are also some other trees, such as European aspen and willows, present within the concentration footprint area (Tarvainen et al., 2007; Rinne et al., 2009). As the emission scheme of the model describes a Scots pine forest, the modelled isoprene concentration is likely to be too low, thus not recreating the observed diurnal cycle of the $\mathrm{OH}$-reactivity (e.g. see Fig. 4 in Sect. 4.1, where the difference in measured and modelled $\mathrm{OH}$-reactivity in the afternoon could be assigned to this underestimation of isoprene concentration).

The OH-reactivity has also been modelled for higher altitudes, and as expected we find that the $\mathrm{OH}$-reactivity decreases with height and is less than $1 \mathrm{~s}^{-1}$ at the top of the boundary layer.

In Fig. 9 daily averaged modelled OH-reactivity in the canopy during winter is presented. The turbulence and mixing are slower during winter, which results in accumulation of reactive compounds in the canopy. This creates a midday peak in the $\mathrm{OH}$-reactivity contrary to the summer time $\mathrm{OH}$ reactivity. Also here, the highest $\mathrm{OH}-$ reactivity is found near ground.

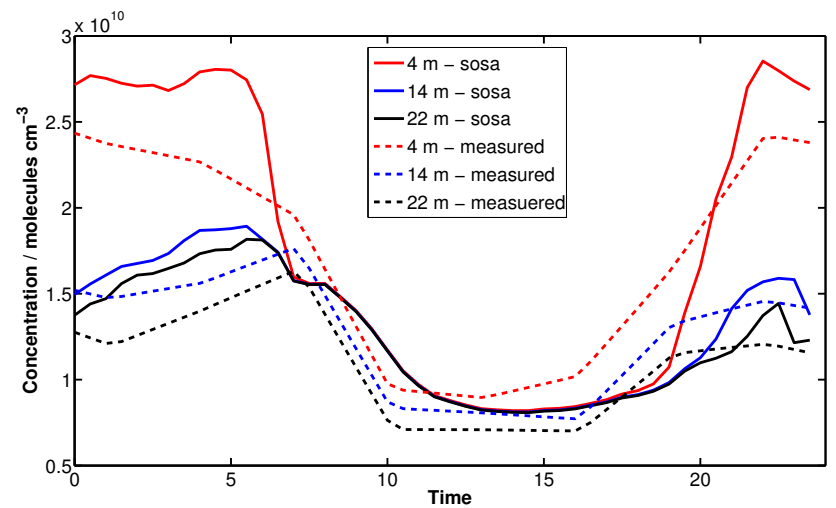

Fig. 8. Daily averaged modelled (named "sosa") and measured sum of monoterpene concentration for 4,14 , and $22 \mathrm{~m}$. The averaging has been done for 26 July to 10 August 2008.

Daily averaged accumulated OH-reactivity for Period A is shown in Fig. 10. The OH-reactivity has been accumulated by summing over the products of OH-reactivity and model layer thickness $(h)\left(\sum R_{\mathrm{OH}, l} \cdot h_{l}\right)$ for every model layer $(l)$ until the boundary layer. The accumulated $\mathrm{OH}$-reactivity correlates with emission patterns of VOCs and peaks in the middle of the day. Even though the "local" OH-reactivity in the individual model layers near ground peaks during night, the total accumulated boundary layer $\mathrm{OH}$-reactivity peaks during day.

\subsection{What is the missing OH-reactivity}

Our model results show that we can only predict approximately $50 \%$ of the total $\mathrm{OH}$-reactivity. This is also the case for previous studies where researchers have calculated the $\mathrm{OH}$-reactivity based on the measured $\mathrm{OH}$ reactive gas concentrations and their corresponding rate coefficient (e.g. di Carlo et al., 2004; Mao et al., 2009). However, the advantages of this complex modelling approach with an explicit chemistry are to be able to gain information about the $\mathrm{OH}-$ reactivity with any wanted time resolution, at any height, and at periods were the $\mathrm{OH}$-reactivity (or the gas concentrations of $\mathrm{OH}$ reactive compounds) are not measured.

As has been proposed by other investigators and in the study by Sinha et al. (2010), a number of reactive unmeasured VOCs are likely to be responsible for the missing $\mathrm{OH}-$ reactivity. We suggest that these unmeasured VOCs are of biogenic origin, since the site is remote from anthropogenic sources.

As previuosly mentioned, we have not forced our model to reproduce the measured isoprene concentrations, and the isoprene contribution to the $\mathrm{OH}$-reactivity is therefore understimated, and could be a possible candidate for the missing $\mathrm{OH}-$ reactivity. Sinha et al. (2010) calculated the OH-reactivity due to contribution from isoprene, using measured isoprene concentrations. The difference in $\mathrm{OH}$-reactivity based on 


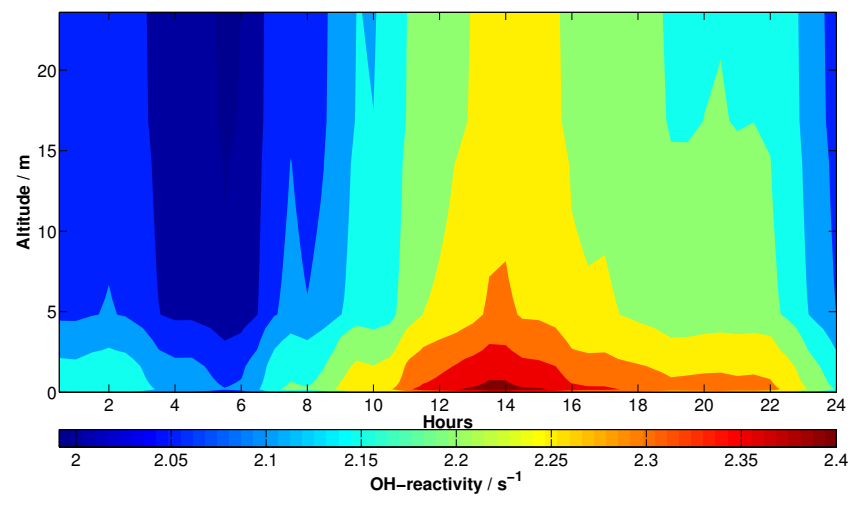

Fig. 9. Daily averaged modelled OH-reactivity as a function of altitude for January, February, March, November and December 2008

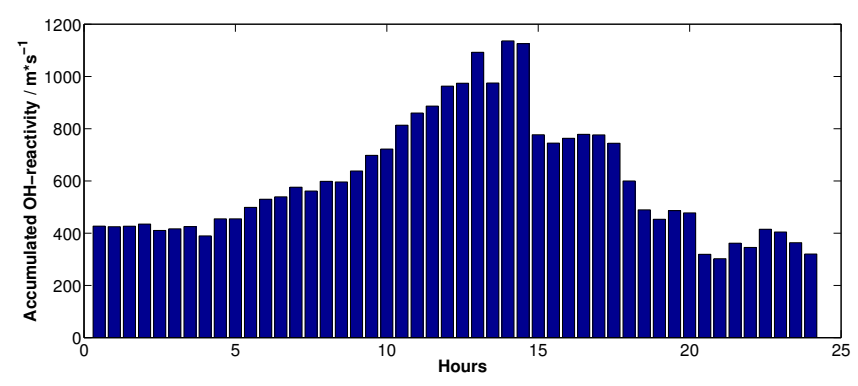

Fig. 10. Daily averaged accumulated OH-reactivity up to the top of the boundary layer for the 13 to the 27 August 2008 .

Sinha et al. (2010) and our calculation due to isoprene reactions is $\sim 0.3 \mathrm{~s}^{-1}$. Isoprene is therefore not a possible candidate for the missing OH-reactivity, since it would only be able to explain $\sim 10-15 \%$ of the missing $\mathrm{OH}$-reactivity.

Unfortunately, there are large uncertainties on rate constants in general, which is a particularly large problem during this study, since it is from these that the OH-reactivity is calculated. Often when evaluators come to compare data for the same reaction studied by more than one group of investigators and involving different techniques, the rate coefficient differ by a factor of 2 or even more (Atkinson et al., 1992). However, for many reactions between $\mathrm{OH}$ and VOCs, no experimental data exist, and the rate coefficients are only estimates, increasing the uncertainty even further. We have performed a simple sensitivity study, where the rate constants for reactions between $\mathrm{OH}$ and the 9 monoterpenes included in the model, isoprene, methane, acetaldehyde, acetone, formaldehyde, methanol and 2-methyl-3-buten-2-ol have been varied. By multiplying all these rate constants by a factor of 2, we were able to increase the modelled $\mathrm{OH}$ reactivity by $40 \%$. By multiplying the rate constants by a factor of 0.5 , we lowered the $\mathrm{OH}$-reactivity by $24 \%$. The large uncertainties on the rate constants are therefore one possible explanation for the missing $\mathrm{OH}$-reactivity. However, the real errors in the rate constants may well in practice have a cancelling effect.

\subsection{Consequences for secondary aerosol formation}

The still missing $\mathrm{OH}$-reactivity affects our understanding of photochemical reactions and secondary product formation in the atmosphere. If the missing $\mathrm{OH}$-reactivity is due to unknown reactions between $\mathrm{OH}$ and unknown organic compounds - primary emitted as well as secondary oxidation products, a variety of impacts may be observed, which could serve as precursors of secondary organics aerosols and significantly increase SOA formation (Chatani et al., 2009).

On the 23 August, the only new particle formation event during the measured period was observed. The missing $\mathrm{OH}-$ reactivity increased until the end of the event, and then decreased shortly after. On the 14 and 24 August less well defined events were observed; on 14th formation of $<10 \mathrm{~nm}$ particles were seen, and on 24th two weak events were observed. A clear rise in the missing OH-reactivity on $14 \mathrm{Au}-$ gust and during the first weak event the 24 August were equally observed. However, the pattern was not repeated during the last event on the 24th. Due to the generally high fluctuation in the measured OH-reactivity and lack of new particle formation events, we are not able to make any clear conclusions. However, the observed rise in missing $\mathrm{OH}-$ reactivity during an event could be explained by more reaction between $\mathrm{OH}$ and some of these unknown organics. Since the rise is seen already in the early states of the particle events, it could be suggested that the $\mathrm{OH}$ oxidized compounds participate in the nucleation or condense on the newly formed clusters and help them grow. However, we saw no correlation between missing OH-reactivity and the condensation sink (coefficient of determination, $R^{2}$, of 0.06 ), nor between measured OH-reactivity and condensation sink (coefficient of determination, $R^{2}$, of 0.09). It therefore seems unlikely that $\mathrm{OH}$ loss to surface of particles will have any significant contribution to the missing $\mathrm{OH}-$ reactivity.

\subsection{Future plans}

Unfortunately $\mathrm{OH}$ concentrations were not measured during summer 2008, why we cannot validate the modelled $\mathrm{OH}$ concentrations. Our future plans are to write a paper focusing on the $\mathrm{OH}$ budget in boreal forests. This will include measurements and model results from the HUMPPA-COPEC-2010 (Hyytiälä United Measurement of Photochemistry and Particles in Air - Comprehensive Organic Particle and Environmental Chemistry 2010) campagin 2010 (Williams et al., 2011). Here we will also include $\mathrm{OH}$ recycling mechanisms (Taraborrelli et al., 2009) in the model runs, and discuss potential missing $\mathrm{OH}$ source terms. 


\section{Conclusions}

We have modelled the total OH-reactivity over a boreal forest. We found that we are currently able to simulate only $\sim 30-50 \%$ of the total measured $\mathrm{OH}$ sink term. The model simulations show that the relative contribution of inorganic and organic sinks vary significantly with season, with the organic compounds being the largest sink during summer, and inorganic compounds dominating during winter. Of the organic compounds, monoterpenes were found to be a major sink for the modelled $\mathrm{OH}$-reactivity. We also showed that the $\mathrm{OH}$-reactivity decreased with height and that a peak is found near ground during night correlating with monoterpene concentration. We suggest that the missing reactivity can be a combination of unmeasured biogenic species and uncertainties in the $\mathrm{OH}$ rate coefficients.

Acknowledgements. We thank Domenico Taraborrelli for helpful discussions and the Biogenic Hydrocarbon Fluxes group at the University of Helsinki for providing and measuring gas concentrations. Furthermore, the financial support by the Danish Chemical Society, the Helsinki University Centre for Environment (HENVI), the Academy of Finnish Center of Excellence program (FCoE, project no. 1118615), the European Research Council (ERC) and computational resources from CSC - IT Center for Science Ltd are all gratefully acknowledged.

Edited by: K. Carslaw

\section{References}

Apel, E. C., Emmons, L. K., Karl, T., Flocke, F., Hills, A. J., Madronich, S., Lee-Taylor, J., Fried, A., Weibring, P., Walega, J., Richter, D., Tie, X., Mauldin, L., Campos, T., Weinheimer, A., Knapp, D., Sive, B., Kleinman, L., Springston, S., Zaveri, R., Ortega, J., Voss, P., Blake, D., Baker, A., Warneke, C., Welsh-Bon, D., de Gouw, J., Zheng, J., Zhang, R., Rudolph, J., Junkermann, W., and Riemer, D. D.: Chemical evolution of volatile organic compounds in the outflow of the Mexico City Metropolitan area, Atmos. Chem. Phys., 10, 2353-2375, doi:10.5194/acp-10-23532010, 2010.

Atkinson, R., Baulch, D. L., Cox, R. A., Hampson, Jr., R. F., Kerr, J. A., and Troe, J.: Evaluated kinetic and photochemical data for atmospheric chemistry, Supplement IV, J. Phys. Chem. Ref. Data, 21, 1125-1568, 1992.

Boy, M. and Kulmala, M.: The part of the solar spectrum with the highest influence on the formation of SOA in the continental boundary layer, Atmos. Chem. Phys., 2, 375-386, doi:10.5194/acp-2-375-2002, 2002.

Boy, M., Rannik, U., Lehtinen, K., Tarvainen, V., Hakola, H., and Kulmala, M.: Nucleation events in the continental boundary layer: Long-term statistical analysis of aerosol relevant characteristics, J. Geophys. Res., 108, 4667-4679, 2003.

Boy, M., Petäjä, T., Dal Maso, M., Rannik, Ü., Rinne, J., Aalto, P., Laaksonen, A., Vaattovaara, P., Joutsensaari, J., Hoffmann, T., Warnke, J., Apostolaki, M., Stephanou, E. G., Tsapakis, M., Kouvarakis, A., Pio, C., Carvalho, A., Römpp, A., Moortgat, G., Spirig, C., Guenther, A., Greenberg, J., Ciccioli, P., and Kulmala,
M.: Overview of the field measurement campaign in Hyytiälä, August 2001 in the framework of the EU project OSOA, Atmos. Chem. Phys., 4, 657-678, doi:10.5194/acp-4-657-2004, 2004.

Boy, M., Sogachev, A., Lauros, J., Zhou, L., Guenther, A., and Smolander, S.: SOSA - a new model to simulate the concentrations of organic vapours and sulphuric acid inside the ABL Part 1: Model description and initial evaluation, Atmos. Chem. Phys., 11, 43-51, doi:10.5194/acp-11-43-2011, 2011 a.

Boy, M., Smolander, S., He, Q., and Bäck, J.: Emission of VOC's from Scot pine forest in southern Finland: Model and measurement intercomparison, Biogeosciences, submitted, 2011b.

Chatani, S., Shimo, N., Matsunaga, S., Kajii, Y., Kato, S., Nakashima, Y., Miyazaki, K., Ishii, K., and Ueno, H.: Sensitivity analyses of $\mathrm{OH}$ missing sinks over Tokyo metropolitan area in the summer of 2007, Atmos. Chem. Phys., 9, 8975-8986, doi:10.5194/acp-9-8975-2009, 2009.

Damian, V., Sandu, A., Damian, M., Potra, F., and Carmichael, G. R.: The Kinetic PreProcessor KPP - A software environment for solving chemical kinetics, Comput. Chem. Eng., 26, 1567-1579, 2002.

de Gouw, J. and Warneke, C.: Measurements of volatile organic compounds in the earths atmosphere using proton-transferreaction mass spectrometry, Mass Spectrom. Rev., 26, 223-257, 2007.

DeMore, W. B., Sander, S. P., Golden, D. M., Hampson, R. F., Kurylo, M. J., Howard, C. J., Ravishankara, A. R., Kolb, C. E., and Molina, M. J.: Chemical kinetics and photochemical data for use in stratospheric modeling, JPL Pub. No. 97-4, Jet Propulsion Laboratory, 1997.

Di Carlo, P., Brune, W. H., Martinez, M., Harder, H., Lesher, R., Ren, X., Thornberry, T., Carroll, M. A., Young, V., Shepson, P. B., Riemer, D., Apel, E., and Campbell, C.: Missing OH Reactivity in a Forest: Evidence for Unknown Reactive Biogenic VOCs, Science, 304, 722-725, 2004.

Faloona, I., Tan, D., Brune, W., Hurst, J., Barket Jr., D., Couch, T. L., Shepson, P., Apel, E., Riemer, D., Thornberry, T., Carroll, M. A., Sillman, S., Keeler, G. J., Sagady, J., Hooper, D., and Paterson, K.: Nighttime observations of anomalously high levels of hydroxyl radicals above a deciduous forest canopy, J. Geophys. Res., 106, 24315-24333, 2001.

Goldstein, A. H. and Galbally, I. E.: Known and Unexplored Organic Constituents in the Earth's Atmosphere, Environ. Sci. Technol., 41, 1514-1521, 2007.

Guenther, A., Karl, T., Harley, P., Wiedinmyer, C., Palmer, P. I., and Geron, C.: Estimates of global terrestrial isoprene emissions using MEGAN (Model of Emissions of Gases and Aerosols from Nature), Atmos. Chem. Phys., 6, 3181-3210, doi:10.5194/acp-63181-2006, 2006.

Haapanala, S., Rinne, J., Hakola, H., Hellén, H., Laakso, L., Lihavainen, H., Janson, R., O’Dowd, C., and Kulmala, M.: Boundary layer concentrations and landscape scale emissions of volatile organic compounds in early spring, Atmos. Chem. Phys., 7, 1869-1878, doi:10.5194/acp-7-1869-2007, 2007.

Hakola, H., Tarvainen, V., Bäck, J., Ranta, H., Bonn, B., Rinne, J., and Kulmala, M.: Seasonal variation of mono- and sesquiterpene emission rates of Scots pine, Biogeosciences, 3, 93-101, doi:10.5194/bg-3-93-2006, 2006.

Hari, P. and Kulmala, M.: Station for measuring ecosystematmosphere relations (SMEAR II), Boreal Environ. Res., 10, 
315-322, 2005.

Hofzumahaus, A., Rohrer, F. Lu, K., Bohn, B., Brauers, T., Chang, C-C., Fuchs, H., Holland, F., Kita, K., Kondo, Y., Li, X., Lou, S., Shao, M., Zeng, L., Wahner, A., and Zhang, Y. Amplified Trace Gas Removal in the Troposphere, Science, 324, 17021704, 2009.

Holzinger, R., Lee, A., Paw, K. T., and Goldstein, U. A. H.: Observations of oxidation products above a forest imply biogenic emissions of very reactive compounds, Atmos. Chem. Phys., 5, 67-75, doi:10.5194/acp-5-67-2005, 2005.

Jenkin, M. E., Saunders, S. M., and Pilling, M. J.: The tropospheric degradation of volatile organic compounds: A protocol for mechanism development, Atmos. Environ., 31, 81-104, 1997.

Kovacs, T. A. and Brune, W. H.: Total $\mathrm{OH}$ loss rate measurement, J. Atmos. Chem., 39, 105-122, 2001.

Kovacs, T. A., Brune, W. H., Harder, H., Martinez, M., Simpas, J. B., Frost, G. J., Williams, E., Jobson, R., Stroud, C., Young, V., Fried, A., and Wert, B.: Direct measurements of urban $\mathrm{OH}$ reactivity during Nashville SOS in summer 1999, J. Environ. Monit., 5, 68-74, 2003.

Kulmala, M., Haemeri, K. K., Aalto, P., Maekelae, J., Pirjola, L., Nilsson, E. D., Buzorius, G., Rannik, U., Dal Maso, M., Seidl, W., Hoffmann, T., Jansson, R., Hansson, H.-C., O’Dowd, C., and Viisanen, Y: Overview of the international project on biogenic aerosol formation in the boreal forest (BIOFOR), Tellus B, 53, 324-343, 2001.

Kurpius, M. R. and Goldstein, A. H.: Gas-phase chemistry dominates $\mathrm{O}_{3}$ loss to a forest, implying a source of aerosols and hydroxyl radicals to the atmosphere, Geophys. Res. Lett., 30, 13711374, 2003.

Lelieveld, J., Butler, T. M., Crowley, J. N., Dillon, T. J., Fischer, H., Ganzeveld, L., Harder, H., Lawrence, M. G., Martinez, M., Taraborrelli, D., and Williams, J.: Atmospheric oxidation capacity sustained by a tropical forest, Nature, 452, 737-740, 2008.

Lou, S., Holland, F., Rohrer, F., Lu, K., Bohn, B., Brauers, T., Chang, C.C., Fuchs, H., Häseler, R., Kita, K., Kondo, Y., Li, X., Shao, M., Zeng, L., Wahner, A., Zhang, Y., Wang, W., and Hofzumahaus, A.: Atmospheric $\mathrm{OH}$ reactivities in the Pearl River Delta - China in summer 2006: measurement and model results, Atmos. Chem. Phys., 10, 11243-11260, doi:10.5194/acp-10-11243-2010, 2010.

Mao, J., Ren, X., Brune, W. H., Olson, J. R., Crawford, J. H., Fried, A., Huey, L. G., Cohen, R. C., Heikes, B., Singh, H. B., Blake, D. R., Sachse, G. W., Diskin, G. S., Hall, S. R., and Shetter, R. E.: Airborne measurement of $\mathrm{OH}$ reactivity during INTEX-B, Atmos. Chem. Phys., 9, 163-173, doi:10.5194/acp-9-163-2009, 2009.

Maris, C., Chung, M. Y., Lueb, R., Krischke, U., Meller, R., Fox, M. J., and Paulson, S. E.: Development of instrumentation for simultaneous analysis of total non-methane organic carbon and volatile organic compounds in ambient air, Atmos. Environ., 37, 149-158, 2003.

Martinez, M., Harder, H., Kubistin, D., Rudolf, M., Bozem, H., Eerdekens, G., Fischer, H., Klüpfel, T., Gurk, C., Königstedt, R., Parchatka, U., Schiller, C. L., Stickler, A., Williams, J., and Lelieveld, J.: Hydroxyl radicals in the tropical troposphere over the Suriname rainforest: airborne measurements, Atmos. Chem. Phys., 10, 3759-3773, doi:10.5194/acp-10-3759-2010, 2010.

O'Dowd, C. D., Aalto, P., Hämeri, K., Kulmala, M., and Hoff- mann, T.: Aerosol formation: Atmospheric particles from organic vapours, Nature, 416, 497-498, 2002.

Ren, X. R., Harder, H., Martinez, M., Lesher, R. L., Oliger, A., Shirley, Y., Adams, J., Simpas, J. B., and Brune, W. H.: $\mathrm{HO}_{\mathrm{x}}$ concentrations and $\mathrm{OH}$ reactivity observations in New York City during PMTACS-NY2001, Atmos. Environ., 37, 3627-3637, 2003.

Rinne, J., Ruuskanen, T. M., Reissell, A., Taipale, R., Hakola, H., and Kulmala, M.: On-line PTR-MS measurements of atmospheric concentrations of volatile organic compounds in a European boreal forest ecosystem, Boreal Environ. Res., 10, 425-436, 2005.

Rinne, J., Taipale, R., Markkanen, T., Ruuskanen, T. M., Hellén, H., Kajos, M. K., Vesala, T., and Kulmala, M.: Hydrocarbon fluxes above a Scots pine forest canopy: measurements and modeling, Atmos. Chem. Phys., 7, 3361-3372, doi:10.5194/acp-73361-2007, 2007.

Rinne, J., Bäck, J., and Hakola, H.: Biogenic volatile organic compound emissions from the Eurasian taiga: current knowledge and future directions, Boreal Environ. Res., 14, 807-826, 2009.

Roberts, J. M., Bertman, S. B., Jobson, T., Niki, H., and Tanner, R.: Measurement of total nonmethane organic carbon (C-y): Development and application at Chebogue Point, Nova Scotia, during the 1993 North Atlantic Regional Experiment campaign, J. Geophys. Res.-Atmos., 103, 13581-13597, 1998

Sadanaga, Y., Yoshino, A., Watanabe, K., Yoshioka, A., Wakazono, Y., Kanaya, Y., and Kajii, Y.: Development of a measurement system of $\mathrm{OH}$ reactivity in the atmosphere by using a laser-induced pump and probe technique., Rev. Sci. Instrum., 75, 2648-2655, 2004.

Sadanaga, Y., Yoshino, A., Kato, S., and Kajii, Y.: Measurements of OH Reactivity and Photochemical Ozone Production in the Urban Atmosphere, Environ. Sci. Technol., 39, 8847-8852, 2005.

Saunders, S. M., Jenkin, M. E., Derwent, R. G., and Pilling, M. J.: Protocol for the development of the Master Chemical Mechanism, MCM v3 (Part A): tropospheric degradation of nonaromatic volatile organic compounds, Atmos. Chem. Phys., 3, 161-180, doi:10.5194/acp-3-161-2003, 2003.

Sinha, V., Williams, J., Crowley, J. N., and Lelieveld, J.: The Comparative Reactivity Method - a new tool to measure total $\mathrm{OH}$ Reactivity in ambient air, Atmos. Chem. Phys., 8, 2213-2227, doi:10.5194/acp-8-2213-2008, 2008.

Sinha, V., Custer, T. G., Kluepfel, T., and Williams, J.: The effect of relative humidity on the detection of pyrrole by PTR-MS for $\mathrm{OH}$ reactivity measurements, Int. J. Mass. Spectrom., 282, 108-111, 2009.

Sinha, V., Williams, J., Lelieveld, J., Ruuskanen, T. M., Kajos, M. K., Patokoski, J., Hellen, H., Hakola, H., Mogensen, D., Boy, M., Rinne, J., and Kulmala, M.: OH Reactivity Measurements within a Boreal forest: Evidence for Unknown Reactive Emissions, Environ. Sci. Technol., 44, 6614-6620, 2010.

Sogachev, A.: A note on two-equation closure modelling of canopy flow, Bound.-Lay. Meteorol., 130, 423-435, 2009.

Sogachev, A. and Panferov, O.: Modification of two-equation models to account for plant drag, Bound.-Lay. Meteorol., 121, 229266, 2006.

Sogachev, A., Menzhulin, G., Heimann, M., and Lloyd, J.: A simple three dimensional canopy planetary boundary layer simulation model for scalar concentrations and fluxes, Tellus B, 54, 784- 
$819,2002$.

Sogachev, A., Panferov, O., Gravenhorst, G., and Vesala, T.: Numerical analysis of flux footprints for different landscapes, Theor. Appl. Climatol., 80, 169-185, 2005.

Taipale, R., Ruuskanen, T. M., Rinne, J., Kajos, M. K., Hakola, H., Pohja, T., and Kulmala, M.: Technical Note: Quantitative long-term measurements of VOC concentrations by PTR-MS measurement, calibration, and volume mixing ratio calculation methods, Atmos. Chem. Phys., 8, 6681-6698, doi:10.5194/acp8-6681-2008, 2008.

Taraborrelli, D., Lawrence, M. G., Butler, T. M., Sander, R., and Lelieveld, J.: Mainz Isoprene Mechanism 2 (MIM2): an isoprene oxidation mechanism for regional and global atmospheric modelling, Atmos. Chem. Phys., 9, 2751-2777, doi:10.5194/acp-92751-2009, 2009.

Tarvainen, V., Hakola, H., Rinne, J., Helln, H., and Haapanala, S.: Towards a comprehensive emission inventory of terpenoids from boreal ecosystems, Tellus B, 59, 526-534, 2007.
Williams, J., Crowley, J., Fischer, H., Harder, H., Martinez, M., Petäjä, T., Rinne, J., Bäck, J., Boy, M., Dal Maso, M., Hakala, J., Kajos, M., Keronen, P., Rantala, P., Aalto, J., Aaltonen, H., Paatero, J., Vesala, T., Hakola, H., Levula, J., Pohja, T., Herrmann, F., Auld, J., Mesarchaki, E., Song, W., Yassaa, N., Nölscher, A., Johnson, A. M., Custer, T., Sinha, V., Thieser, J., Pouvesle, N., Taraborrelli, D., Tang, M. J., Bozem, H., Hosaynali-Beygi, Z., Axinte, R., Oswald, R., Novelli, A., Kubistin, D., Hens, K., Javed, U., Trawny, K., Breitenberger, C., Hidalgo, P. J., Ebben, C. J., Geiger, F. M., Corrigan, A. L., Russell, L. M., Ouwersloot, H., Vilá-Guerau de Arellano, J., Ganzeveld, L., Vogel, A., Beck, M., Bayerle, A., Kampf, C. J., Bertelmann, M., Köllner, F., Hoffmann, T., Valverde, J., González, D., Riekkola, M.-L., Kulmala, M., and Lelieveld, J.: The summertime Boreal forest field measurement intensive (HUMPPA-COPEC-2010): an overview of meteorological and chemical influences, Atmos. Chem. Phys. Discuss., 11, 1592115973, doi:10.5194/acpd-11-15921-2011, 2011. 